\title{
Absorbable Fibrin Sealant Patch
}

National Cancer Institute

\section{Source}

National Cancer Institute. Absorbable Fibrin Sealant Patch. NCI Thesaurus. Code C119748.

A sterile, absorbable surgical sealing patch composed of an equine collag en sponge coated with the coagulation factors human fibrinogen and human thrombin, with potential hemostatic activity. Applied on the wound tissue, the absorbable fibrin sealant patch adheres to the tissue and the solid fibrinogen and thrombin dissolve upon contact with the physiological fluid. In turn, fibrinogen is converted to fibrin monomers by thrombin, and polymerize to form a fibrin clot at the wound surface. This causes the patch to adhere to the wound surface and promotes tissue sealing. This may reduce lymphatic drainage and prevent seroma formation. 